流れの可視化Vol. 7 Suppl. ( 1987 年10月)

\title{
流れの可視化札幌講演会の開催に当たって
}

\author{
流れの可視化学会会長 田古里 哲 夫
}

\section{Message of the President at the Opening of Sapporo Meeting Tetsuo TAGORI}

流れの可視化札显講演会の開催に当たり一言ご挨拟申上げます。

流れの可視化講演会が東京以外の地域で開催されるのは今回で 4 回目になります。第 1 回は昭 和57年長崎, 第 2 回は昭和59年仙台, 第 3 回は昭和60年大阪で開かれました。昨年は流れの可視 化国際シンポジウムがありましたので，1 年開催を遅らせて今回になりました。第 1 回流れの可 視化シンポジゥムが開催されたのは，昭和48年のととでした。今年は流れの可視化シンポジゥム 15周年に当たります。乙の記念すべき15周年に念願の北海道で講演会を開催させていただくこと になり真に慶賀の至りと存じます。

東京以外の地で講演会を開催する目的は，会員の研究発表の機会を增すだけではなく，日頃流 れの可視化に関心を持たれながら出席できなかった方々や，流れの可視化に若干踈遠であられた 方々に出席していただく機会を作り，で理解とで関心を深めていただき，流机の可視化の進歩発 展を促進することにあります。15周年の重要事業に本学会の社団法人化があります。見在申請手 続きを進めていますが, 本講演会により流机の可視化に対する理解と関心が一層高まり, 流れの 可視化の進歩, 利用の拡大, 学術・産業への寄与の発展, 会員増強などの面で法人化に大きな援 助になることを願っています。

幸いにして本講演会には約40編という多くの研究成果が寄せられ，で同慶の至りに存じます。 さらに, 特別講演として北海道大学低温科学研究所青田昌秋教授の「オホーック海と流水」と東 海大学工学部中山泰喜教授の「流れの可視化の現状と将来展望」のお話を拜聴できますととは. 錦上花を添えるむので本講演会を一層允実させるあのであります。また, 関連機器の展示と, 昨 年東京で開催いたしました流れの可視化展「見えない流れの世界展」で展示しました写真バネル の展示む行われます。で出席の方々にはきっとで参考にしていただけるものと思います。さらに 第 3 日には見学会が予定されています。札幌市青少年科学館, 北海道開拓の村の見学は本学会の 活動をより活発にするためにむ有意義なととと存じます。

時間の許す限り会員の皆様の活発なで討論を得まして, 本講演会を一層実り多いむのといたし ますととむに，ロビーや笖親会などでので歓談を通じて愳親の実を一層あげられるよう念願する あのであります。

終わりに, 本講演会の開催に多大ので尽力をいただきました実行委員長室闌工業大学奥田教海 教授をはじめ実行委員会扔よび関係の皆様方に厚く御礼申上げます。 


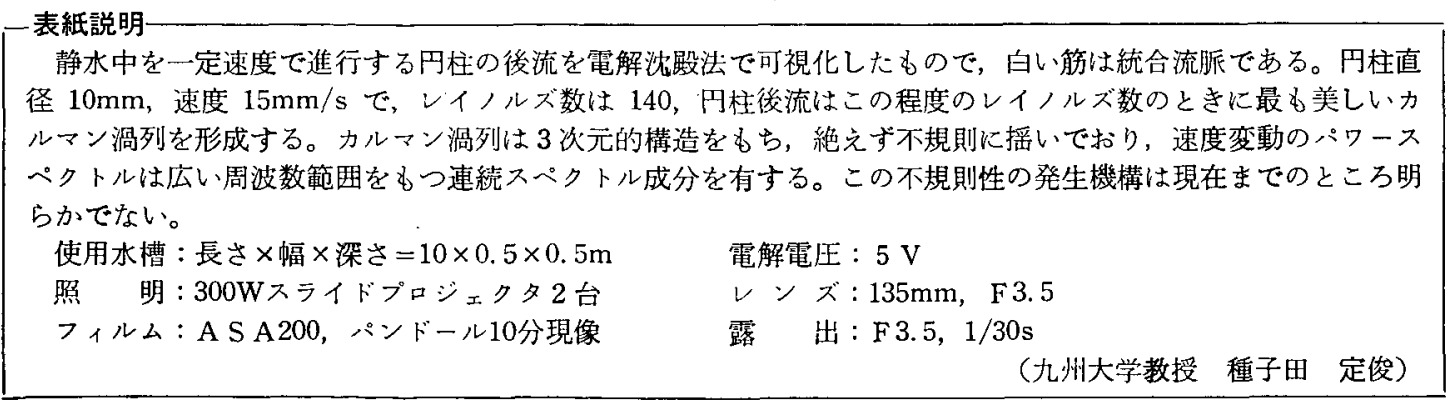

